\title{
ONCOLYTIC VIRAL THERAPY IN CANCER THERAPEUTICS
}

\author{
KRISHNAN VENGADARAGAVA CHARY ${ }^{1 *}$, ANISH BHARATWAJ ${ }^{2}$ \\ ${ }^{1}$ Department of Pharmacology, Saveetha Medical College, Chennai, Tamil Nadu, India. ${ }^{2}$ Department of Final MBBS Part I, Saveetha Medical \\ College, Chennai, Tamil Nadu, India. Email: doctorkrishforu@gmail.com \\ Received: 18 April 2017, Revised and Accepted: 15 June 2017
}

ABSTRACT

Objective: The aim of this study is to provide comprehensive information of oncolytic viral therapy, from the origin to present scenario.

Methods: This observational study was conducted by the Department of Pharmacology, Saveetha Medical College, Chennai between July and December 2016. Date regarding ongoing oncolytic virotherapy trials was retrieved from clinical trial database, United States and Clinical trial registry forum, India. Tamilnogene approval details were obtained from the US-Food and Drug Administration approval new drug approval information.

Results: Eleven ongoing trials in Phase I and Ia are being carried out, of which 4 viral strains such as herpes, adenovirus, measles, and reovirus are used for intracerebral malignancies. Four trials have shown superior effects and seven trial results are yet to be completed.

Conclusion: Oncolytic viral therapy can be as effective as targeted therapy in battling against cancer; however, long-term efficacy and safety should be established from more studies and meta-analysis.

Keywords: Tamilnogene, Oncolytic virus, Virotherapy in cancer.

(C) 2017 The Authors. Published by Innovare Academic Sciences Pvt Ltd. This is an open access article under the CC BY license (http://creativecommons. org/licenses/by/4. 0/) DOI: http://dx.doi.org/10.22159/ajpcr.2017.v10i10.19265

\section{INTRODUCTION}

Oncolytic viral therapy is yet another milestone in targeted chemotherapy; however, the ground work has started as early as in 1950s to use viruses to shut off cancer cell cycle [1]. Despite several hurdles, now, we are able to get a nod for the first oncolytic viral therapy for advanced cases of skin cancer, melanoma.

The tryst with virotherapy began in 1949, when by chance, 2 patients with Hodgkin's Lymphoma went into remission. However, the happy times came with a price of dealing with another entity, namely, hepatitis B [2]. Like many famous discoveries, this was one of chance. Later, a trial was conducted with 22 patients wherein they were administered strains of hepatitis B virus [3]. Of the 22 patients, 4 showed mild forms of recovery. There was one death reported in this trial.

Moreover, then 7 years later, another study was conducted, this time with a significant idea of what we needed and how it probably worked. As mentioned earlier, this study was done with the adenovirus adenoidal, pharyngeal, and conjunctival. The disease against which it was administered was advanced epidermoid cervical carcinoma. There were 30 patients in the trial. The trial was mildly promising mostly because the patients were still alive post inoculation [4]; however, the most significant strain of adenovirus came with the finding and usage of H101 strain. It was approved in 2005 by the Chinese SFDA. However, it is not approved outside of China. It is marketed under the name ONCORINE.

\section{METHODS}

This observational study was conducted by the Department of Pharmacology, Saveetha Medical College, Chennai between July and December 2016. Date regarding ongoing oncolytic virotherapy trials was retrieved from clinical trial database, United States and Clinical trial registry forum, India. Talimogene approval details were obtained from the US-Food and Drug Administration approval new drug approval information.

\section{RESULTS}

Eleven ongoing trials in Phase I and Ia are being carried out, of which 4 viral strain such as herpes, adenovirus, measles, and reovirus are used for intracerebral malignancies. Four trials have shown superior effects and seven trial results are yet to be completed.

\section{DISCUSSION}

\section{How does virotherapy works?}

There are 4 proposed mechanisms of action, each one being strongly expressed in a particular strain and varies with each other [5]. The postulated mechanisms are:

- Cell lysis by replication in the cell: The first possible action and probably the most significant

- In vivo synthesis of proteins and cytotoxic products that is detrimental to the cell

- Induction of antitumour responses, both direct and immune mediated

- Transgene expression and induction cancer cell apoptosis.

Mechanism is illustrated is depicted in Fig. 1.

Current cancer chemotherapy scenario with oncolytic viruses Primary brain tumors are extensively studied under oncolytic therapy in experimental model as well as in clinical trials. Central Nervous system tumors originate from a common progenitor which then differentiates into one of the glial cell types. They generally include astrocytomas, oligodendroglioma, and ependymoma. Glioblastoma multiforme (Grade IV astrocytoma) belongs to a set of tumors called infiltrating astrocytomas.

Genetically engineered herpes simplex virus-dlsptk by Martuza and colleagues, it is lacking the viral thymidine kinase. This component is important for replication in nonreplicating cells. Its deletion thus made it incompetent to divide into cells like neurons and infects the actively dividing glial cells to use the products of cell division. However, it had a major drawback. Viral toxicity could not be controlled because of loss 


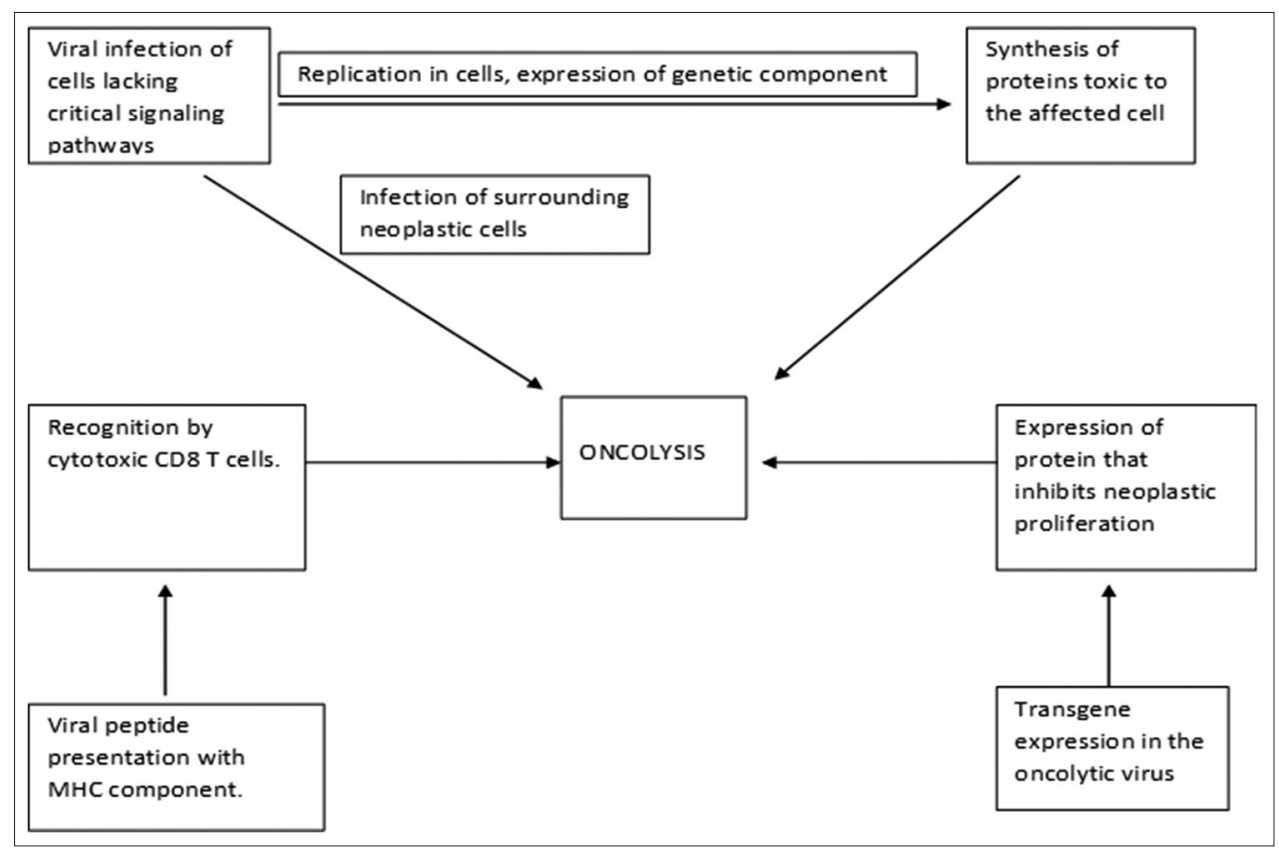

Fig. 1: Illustration of mechanism of action of oncolytic viruses

Table 1: Viruses which are effective against various malignancies in vitro studies

\begin{tabular}{ll}
\hline Viral strain & Malignancy \\
\hline Adenovirus AdV5 strain & Glioma \\
Reovirus & Against various tumors in nude mice model \\
New castle virus & Against pediatric sarcomas \\
Parvovirus & Adult glioma \\
Measles virus & Glioma, medulloblastoma \\
Sabin polio (PVS-RIPO) strain & Adult glioma \\
Vesicular stomatitis virus & Grade IV astrocytoma \\
Seneca valley virus & Pediatric malignancies \\
\hline
\end{tabular}

Table 2: List of oncolytic virotherapy clinical trials under evaluation

\begin{tabular}{|c|c|c|c|c|}
\hline Virus & Strain & Route of administration & $\begin{array}{l}\text { current } \\
\text { phase }\end{array}$ & Result \\
\hline \multirow[t]{2}{*}{ Herpes virus } & G207 & Intratumoral & $\mathrm{I}$ & $\begin{array}{l}\text { Reduced tumor volume in MRI with no serious } \\
\text { ADRs (Phase II in progress) }\end{array}$ \\
\hline & HSV1716 & Intratumoral & II & $\begin{array}{l}3 \text { disease free states and } 5 \text { stable state patients } \\
\text { with no serious ADRs }\end{array}$ \\
\hline \multirow[t]{2}{*}{ Adenovirus } & a) ONYX-015 & Peritumoral & I & No effects noted, further data expected \\
\hline & b) ICOVIR & Intra/Peritumoral & I & Trials in Progress \\
\hline Reovirus & Serotype 3 Dearing & i.v \intratumoral & III & $\begin{array}{l}\text { Unpublished } \\
\left(2^{\text {nd }} \text { trial showed stable patient with } 3 \text { survivors }\right)\end{array}$ \\
\hline Newcastle Disease & HUJ strain/Ulster & & I & 3 long-term survivors \\
\hline Virus & Strain & & II & $\begin{array}{l}\text { Improved OS and PFS compared to nonvaccinated } \\
\text { groups }\end{array}$ \\
\hline Parvovirus & $\mathrm{Hi}-\mathrm{Pv}$ & Intratumoral/Intracerebral & I/IIa & Study completed. Results to be published. \\
\hline Morbillivirus (measles) & M-CEA & Intratumoral/peritumoral & I & Trials in progress \\
\hline & $\begin{array}{l}\text { M-NIS } \\
\text { (For recurrent } \\
\text { Childhood } \\
\text { Medulloblastoma) }\end{array}$ & $\begin{array}{l}\text { Administration in to tumor } \\
\text { bed post resection. }\end{array}$ & Ia & Trial in progress \\
\hline Polio virus & PVSRIPO & Intratumoral & I & Trial expected to complete by 2017 \\
\hline
\end{tabular}

of sensitivity to Ganciclovir whose site of action is the viral thymidine kinase. This prevented further advancement to clinical trials but paved way for better strains [6]. Another herpes strain G207 is showing premising results without infectivity [7]. 
So far, virotherapy studies for meningiomas have been attempted at human-derived models and cultures. One significant study involved patient-derived cultures that were grafted into immunodeficient mice, leading to development of subdural tumors. To this, G47 delta herpes strain was subjected. This extended the survival of the mice with the tumor [8]. Another study involved cultures obtained from 12 glioblastoma patients, following which replication competent adenoviruses were allowed to infect these cultures. Efficient results were obtained and clinical trials are now underway [9].

Apart from viruses mentioned above and central nervous tumors, many other viral strains are being employed for much different indication. Advances in genetic engineering attenuate the viral infectivity while retaining tumor remission property. The list of other oncolytic viral therapy is enlisted in Table 1.

Many clinical trials and metal analysis finding are in need to provide the evidence-based results of oncolytic viral therapy [10]. Cancer prevalence is on inclining trend in both developed and developing nation, and still, there is an unmet need to reduce its morbidity and mortality. Oncolytic virotherapy is expected to cause paradigm shift in cancer therapeutics [11-14].

\section{CONCLUSION}

Oncolytic viral therapy can be as effective as targeted therapy in battling against cancer; however, long-term efficacy and safety should be established from more studies and meta-analysis.

\section{REFERENCES}

1. FDA. FDAApproves Amgen's Injected Immunotherapy for Melanoma. USA: Food and administration; 2015.
2. Kelly E, Russell SJ. History of oncolytic viruses: Genesis to genetic engineering. Mol Ther 2007;15(4):651-9.

3. Hoster HA, Zanes RP, Von Haam E. The association of "viral" hepatitis and Hodgkin's disease; A preliminary report.Cancer Res 1949;9(8):473-80

4. Huebner RJ, Bell JA, Rowe WP, Ward TG, Suskind RG, Hartley JW, et al. Studies of adenoidal-pharyngeal-conjunctival vaccines in volunteers. J Am Med Assoc 1995;159(10):986-9.

5. Meerani S, Yao Y. Oncolytic viruses in cancer therap. Eur J Sci Res 2010;40:1

6. Martuza RL, Malick A, Markert JM, Ruffner KL, Coen DM. Experimental therapy of human glioma by means of a genetically engineered virus mutant. Science 1991;252(5007):854-6.

7. Mineta T, Rabkin SD, Yazaki T, Hunter WD, Martuza RL. Attenuated multi-mutated herpes simplex virus-1 for the treatment of malignant gliomas. Nat Med 1995;1:938-43.

8. Nigim F, Esaki SI, Hood M, Lelic N, James MF, Ramesh V. A new patient-derived orthotopic malignant meningioma model treated with oncolytic herpes simplex virus. Neuro Oncol 2016;18(9):1278-87.

9. Wollmann G, Ozduman K, van den Pol AN. Oncolytic virus therapy of glioblastoma multiforme: Concepts and candidates. Cancer $\mathrm{J}$ 2012;18(1):69-81.

10. ClinicalTrials.gov. A Service of the U.S. National Institutes of Health. [Last updated on 2017 Mar; Last cited 2017 Mar]. Available from: https://www.clinicaltrials.gov.

11. Reddy DR, Kalyani G, Pradeep K, Asif MD, Kartheek D, Gangabhavani $\mathrm{M}$. The survey of cancer patients in the region of guntur: Based on hospital registry. Int J Pharm Pharm Sci 2017;9(2):228-32.

12. Gupta M, Dahiya J, Marwaha RK, Dureja H. Therapies in cancer treatment: An overview. Int J Pharm Pharm Sci 2005;7(4):1-9.

13. Krishnan V, Sadasivan U. Angiogenesis inhibitors in cancer therapeutics. Int J Basic Clin Pharmacol 2014;3(1):24-6.

14. Muthusamy P, Chary KV, Nalini G. Metronomic chemotherapy: Seems prowess to battle against cancer in current scenario. J Clin Diagn Res 2016;10(11):9-13 